\title{
Preparation Of Standard Operating Procedures of Business Management On Smes Safira Handmade Batam
}

\author{
$1^{\text {st }}$ Estri Oktriyani \\ Department Business Management \\ Politeknik Negeri Batam \\ Batam, Kepulauan Riau Indonesia \\ Estriyani6@gmail.com
}

\author{
$2^{\text {nd }}$ Shinta Wahyu Hati \\ Department Business Management \\ Politeknik Negeri Batam \\ Batam, Kepulauan Riau Indonesia \\ Shinta@polibatam.ac.id
}

\begin{abstract}
The administration and book keeping system in a business is one of the factors that can influence the success of a business. Rules or guidelines that can regulate the running of business processes are also an important factor in running a business. UKM Safira Handmade Batam requires an application system that can facilitate this business in processing data related to business management and also a Standard Operating Procedure (SOP) which is expected to be a guideline or reference in conducting business management. In this research, an application system and business management SOP will be designed for Batam Safira Handmade UKM. Data collection methods used in this study were observation, interviews and documentation. While the method used in and SOP is made by summarizing and analyzing a number of data obtained from the process of collecting data and evaluating business processes that have been carried out before. From this study producing Business Management SOPs that can be used as guidelines in managing business better and more accurate in accordance with existing procedures.
\end{abstract}

Keywords-Business management, raw material, sales, marketing, finance report, Standard Operating Procedure (SOP)

\section{INTRODUCTION}

\section{A. Background}

In this current era, graduates of Universities in Batam prefer to work in private companies or government institutions. Many of them are competing to get the best position and income. It makes more and more job seekers uncertain in the direction because of the lack of jobs and increasing the number of unemployed people in Batam. In addition, the development of the manufacturing industry in Batam is the leading sector that contributes the most to Gross Regional Domestic Product compared to other sectors. This is based on the contribution of the manufacturing industry's output during the 2015-2017 period.

The impact of this is certainly there, from the increasing number of unemployed people that can cause adverse effects, such as economic instability due to a decrease in people's purchasing power, social inequality, and problems of crime among the community due to increased poverty, and others. On of the solution that can be taken from the impacts that can occur due to the large number of unemployed people is entrepreneurship.

According to the result of research by Irawati \& Hati $(2014)^{[1]}$, the factor that can motivate entrepreneurial interest among students or young people are self-success and tolerance toward risk.

Entrepreneurial interest for a beginner can be started by opening a small business in accordance with the interest, hobbies, abilities and knowledge which owned by them. Small business are commonly referred to as Small and Medium Enterprises (Which will later be called SMEs).

One of the developing SMEs in Batam City is SMEs in the fashion field. Fashion is an increasingly promising field of business. The SMEs Safira Handmade Batam, it is a SMEs that was established in Batam which is engaged in Islamic fashion. SMEs Safira Handmade Batam sells several self-produced hijab models, which have now reached 12 types of hijab that have been produced. SMEs Safira Handmade Batam has been established for one and a half years by someone who does not have a background in knowledge about business management but has a hobby of entrepreneurship.

Good business management is business management that has a basic and reference during the management process. One of the alternative solution to this problem, SMEs Safira Handmade Batam can implement the Standard Operating Procedure (SOP) in the business management process to streamline the flow of business. The Standard Operaring Procedure (SOP) is a set of written instructions that are used for routine activities or activities that are repeatedly done ${ }^{[2]}$

The administration and bookkeeping system is one of the factors that can cause the failure of a business. Then the administration system of a business must be managed properly.

\section{B. Formulation of the problem}

Based on the background, the formulation of the problem are as follow:

1. How to identify business management in SMEs Safira Handmade Batam? 
2. How to make a business management SOP for SMEs Safira Handmade Batam?

3. How to implement and evaluate the application of SOPs in SMEs Handmade Safira Batam?

\section{Theoritical Framework}

\section{LITERATURE REVIEW}

\section{Small-to-medium enterprise (SMEs)}

According to the Central Bureau of Statistics, a business run by less than 4 workers is called a home industry, then if the business is run by 5-19 workers it is classified as a small industry and if the business is run by 20-99 workers are classified as medium industries.

\section{Small business management}

According to Balderton in Adisasmita (2011) ${ }^{[4]}$, the term management is the same as management which is moving, organizing, and directing human efforts to effectively utilize material and facilities to achieve a goal.

\section{Standard Operating Procedure (SOP)}

According to Tjipto (2011) ${ }^{[5]}$, Standard Operational Procedure (SOP) is a guideline or reference for carrying out work duties in accordance with the use and performance appraisal tools of government agencies based on technical, administrative and procedural indicators according to work procedures, work procedures and work processes for the unit concerned.

\section{Raw Material Inventory}

Raw material inventory is raw material that is stored and will be used to fulfill certain objectives such as the smooth production process ${ }^{[6]}$.

\section{Raw Material Purchase}

According to Mukrie in Purwaningtyas $(2013)^{[7]}$, the purchase of raw materials is a series of activities to supply types, quantities, specifications / quality of raw materials in accordance with the applicable regulations / policies in the institution.

\section{Sales}

Sales is one of the activities carried out by the company to maintain its business to grow and to get the desired profit or profit. According to Nafarin (2009) ${ }^{[8]}$, sales also means the process of selling activities, namely activities from selling prices to products distributed to consumers / buyers.

\section{Financial Administration}

Financial administration is all activities of the company with efforts to obtain company funds and businesses to use and allocate these funds efficiently ${ }^{[9]}$.

\section{Financial Report}

According to S Mulyawan in Purwanti (2017) ${ }^{[10]}$, financial report is a testing tool of the work of the bookkeeping section used to determine or assess the company's financial position.

\section{METHODS OF RESEARCH}

\section{A. Method of Research or Research Design}

The design or type of this research is carried out with a qualitative descriptive approach. According to (Prabowo, 2013) ${ }^{[12]}$ Qualitative descriptive approach is a method of processing data by analyzing factors related to the object of research by presenting data more deeply to the object of research.

\section{B. Object and Scope of this research}

The objects in this study are documents and processes related to purchase transactions, usage, raw material stock updates, product sales and financial reports of SMEs Safira Handmade Batam.

The scope of this research includes transaction management, administration, finance and business processes at SMEs Safira Handmade Batam.

\section{Data Collection Thecnique}

1. Observation is a technique of collecting data by conducting surveys directly into the field. The author conducted a direct survey on SMEs Safira Handmade to conduct research related data collection.

2. Interview is a technique of collecting data by giving several questions to the interviewee and answered directly by the interviewee. The author conducted an interview directly to the owner of SMEs Safira Handmade Batam.

3. Documentation is a technique of collecting data by obtaining data in the form of written data such as data on raw material lists, product lists, etc.

\section{SOP Preparation Method}

The steps in the preparation of SOPs are as follows:

1. Determining the scope of SOP

2. Compiling SOP
a. The step of needs identification
b. The step of collecting data
c. The step of preparation
d. The step of forming
e. The step of testing
f. The step of perfection
g. The step of implementation

\section{RESULTS AND DISCUSSION}

\section{A. General Description of the Company}

SMEs Safira Handmade Batam is a small-to-medium business in islamic fashion, sell their own processed goods, which are various kinds of hijab which now have 12 types of hijab. This business began on July 7, 2017 by Eka Safira, as the Owner of this SMEs.

The owner began to set up this business at his parents' residence located in Tanjung Sengkuang RT 05 RW 01 No 73, Batu Ampar. Besides that, he also conducts online marketing through Instagram social media with the username "Safira Hanmade" and Facebook. Since October 2018, this SMEs also started selling its products through the official online shopping site. 


\section{B. Result}

The identification of business management on SMEs Safira Handmade Batam

This research identified Safira Handmade Batam for 4 (four) business processes, namely Raw Material Inventory Process, Raw Material Purchasing Process, Marketing and Sales Process, Financial Report Process. The identified results are as follows :

\section{Raw Material Inventory}

Raw material inventory starting from the purchase of raw materials carried out in accordance with the demand for the procurement of raw materials needed. Raw materials that have been purchased will be received and arranged according to the type of raw material in the storage of raw materials. The production section will process raw materials into finished products that are ready for sale according to existing orders. With the purchase of raw materials and production activities, the raw materials will experience an increase and decrease in the amount of stock. So monitoring the amount of raw material stock must be done.

\section{Purchasing Raw Materials}

Purchase of raw materials is based on the demand for products from customers. The demand requires a production process that requires raw materials in the process. Before the production process is carried out, the raw material stock will be checked first to see its availability. Raw materials that are out of stock or inadequate will be made a list for purchase. When going to make a purchase, the important thing to do is to choose suppliers. Selection of suppliers by sending an offer letter to suppliers to get information on prices, quality of goods and requirements that must be met.

After making an order to the supplier that has been chosen by sending an order letter about the goods and the quantity of goods to be ordered. Goods that have been ordered will be received and inspected regarding the type, quantity and quality of the goods. After the item has been ascertained to be appropriate, the documents relating to the purchase will be examined and archived as a reference in making payments to suppliers.

\section{Sales and Marketing}

Market segmentation of hijab products of SMEs Safira Handmade Batam preferably to the community of Muslims, women, adolescents to adulthood along with various sizes and types of materials used.

Targeting of SMEs Safira Handmade Batam is a woman who likes the use of modern and up-to-date hijab and can be adjusted to the time of use.

Positioning of hijab products for SMEs Safira Handmade Batam is located in the type of hijab which can but cannot be separated from the modern and trendy concept.

The marketing process undertaken by UKM Safira Handmade Batam has been using the marketing mix strategy by determining each element as a plan.
Sales done by SMEs Safira Handmade Batam is through social media intermediaries by choosing products that are on Instagram posts, Facebook and Shopeee UKM Safira Handmade Batam.

\section{Financial Report}

The financial statement flow in SMEs Safira Handmade Batam starts from the transactions that occur such as purchases, sales or other forms of transactions. Furthermore, the transactions that occur will produce transaction evidence that should always be archived to become evidence in the process of preparing the next financial report. But what actually happened in SMEs Safira Handmade Batam, the evidence of the transactions that occurred were not all properly stored or archived. So that there are transactions that have no evidence and cannot be recorded as expenses or income.

\section{Making Standard Operating Procedure (SOP) for Batam Handmade Safira UKM}

The making of a Standard Operating Procedure (SOP) is made based on the results of identification of business management that has occurred previously which is then adjusted based on the needs needed SMEs Safira Handmade Batam to reduce errors in the business processes.

The preparation of this SOP produces a draft SOP that is expected to help improve the problems identified in each business process found in the previous process. This is done by compiling an SOP with improvements as follows : 1. SOP for Raw Material Inventory

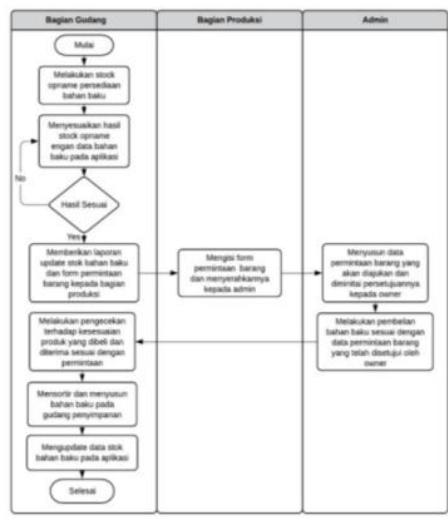

Figure 1. SOP for Raw Material Inventory

2. SOP for Raw Material Purchases

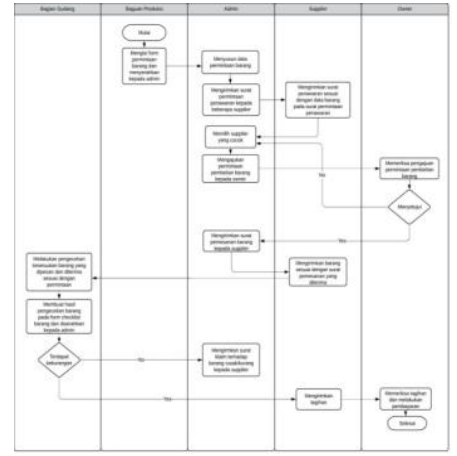

Figure 2. SOP for Raw Material Purchases 
3. SOP for Marketing and Sales

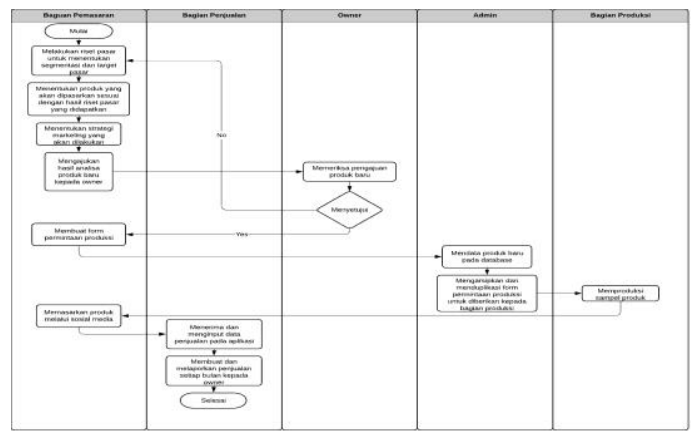

Figure 3. SOP for Raw Marketing and Sales

4. SOP for Financial Report

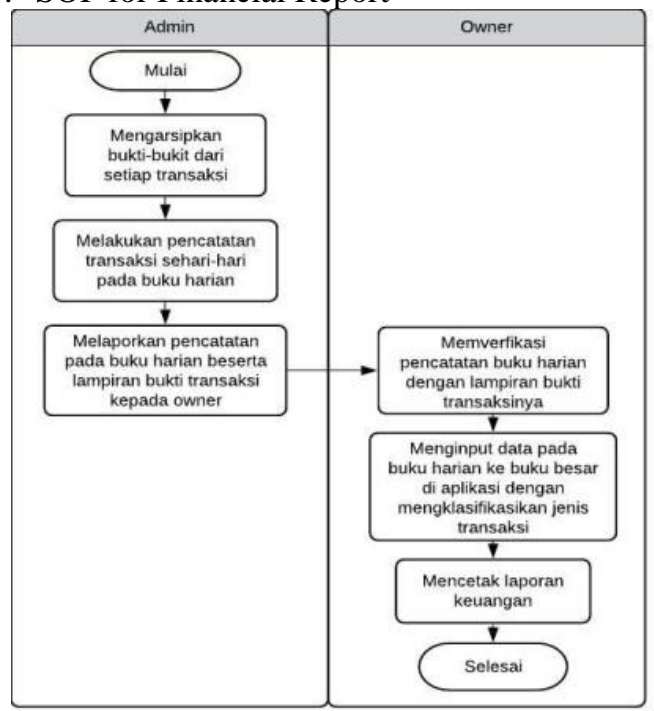

Figure 4. SOP for Financial Report

The implementation and evalutation SOP on SMEs Safira Handmade Batam

Standard Operating Procedure (SOP) has been arranged and implemented on SMEs Safira Handmade Batam starting from April 1 to May 30, 2019. From the implementation, the researcher evaluates the effect of SOP implementation on SMEs Safira Handmade Batam. There is a whole process of business management on SMEs Safira Handmade Batam, the implementation of this SOP has a good impact and provides improvements to the identified shortcomings seen from the results of the implementation control table in the evaluation process.

\section{CONCLUSIONS AND RECOMMENDATION}

\section{A. Conclusions}

Based on the results of research on application design and Business Management SOP on SMEs Safira Handmade Batam some conclusions can be taken as follows :

1. Identify business management at SMEs Safira Handmade Batam as been done and found some identification results in the form of shortages in the process of raw material inventory, raw material purchase, sales and marketing, and financial report.

2. This research has succeeded in creating a Standard Operating Procedure (SOP) with the scope of business needed by the owner delivered during the interview process. So that the SOPs produced are SOPs for Raw Materials, SOPs for Raw Material Purchases, SOPs for Marketing and Sales, SOPs for Financial Statements. All SOPs are made with the aim of improving the shortcomings and ineffectiveness of business processes that have previously been carried out.

3. Standards Operating Procedure (SOP) that was completed designed was implemented on SMEs Safira Handmade Batam for 2 months working days, namely from April 1 to May 31, 2019 and after that the implementation results are evaluated to determine the suitability between design planning and the results of its implementation.

\section{B. Recommendation}

Based on the research that has been done, suggestions that can be taken into consideration for research and also for the company going forward are as follows:

1. The results of identifying business management that has been carried out in the form of errors or shortcomings that occurred in the previous business process are expected not to be repeated again so that business management on SMEs Safira Handmade Batam keep going well and grow.

2. Standard Operating Procedure (SOP) in the business process of raw material inventories, book purchases, marketing and sales, financial reports on SMEs Safira Handmade Batam that has been made amd expected to keep continue to be implemented in a disciplined and consistent manner to reduce errors in work procedures and make repairs if needed.

3. This SOP is expected to continue to be implemented and evaluated on a continuous basis so that it can run effectively and efficiently and help SMEs Safira Handmade Batam in managing their business.

\section{REFERENCE}

[1] Irawati, R., \& Hati, S. W. (2014). Faktor-Faktor yang Memotivasi MInat Mahasiswi dalam Berwirausaha di Politeknik Negeri Batam. Jurnal Ekonomi Pendidikan dan Kewirausahaan. Vol. 2. No. 1. ISSN : 2303-324X.

[2] Hartatik, I. P. (2014). Buku Pintar Membuat S.O.P. Jogjakarta: FlashBooks.

[3] Jati, B. M., \& Priyambodo, K. T. (2015). Kewirausahaan Technopreneurship untuk Mahasiswa Ilmu-Ilmu Eksakta. Yogyakarta: ANDI.

[4] Adisasmita, Rahardjo. 2011. Pengelolaan, Pendapatan \& Anggaran Daerah. Yogyakarta: Graha Ilmu.

[5] Atmoko, Tjipto. 2011. Standar Operasional Prosedur (SOP) dan Akuntabilitas Kinerja Instansi Pemerintah. Unpad, Bandung.

[6] Surapati, G. S. (2017). Perencanaan dan Pengendalian Persediaan Bahan Baku dengan Menggunakan Metode Economic Order Quantity (EOQ) pada UKM Barelang Kompos. Skripsi Program Studi Admintrasi Bisnis Terapan.

[7] Purwaningtyas, S. (2013). Gambaran Penyelenggaraan Makan di Pondok Pesantren Al-Qodiri Kabupaten Jember. Skripsi Bagian Kesehatan Masyarakat.

[8] Nafarin. (2009). Penganggaran Perusahaan. Jakarta: Salemba Empat.

[9] Sidik, Betha. (2010). MySQL untuk Pengguna, Administrator, dan Pengembangan Aplikasi Web. Bandung: Informatika. 
[10] Purwanti, E. (2017). Analisis Pengetahuan Laporan Keuangan pada UMKM Industri Konveksi di Salatiga. Jurnal Among Makarti. Vol.1 No.20. 20 Desember 2017

[11]Sugiyono, Arief \& Edy. (2016). Panduan Praktis Dasar Analisa Laporan Keuangan. Jakarta: PT Grasindo.

[12]Prabowo, H. A. (2013). Analisis Pemanfaatan Buku Elektronik (EBook) oleh Pemustaka di Perpustakaan SMA Negeri 1 Semarang. Jurnal Ilmu Perpustakaan. Vol. 2. No.2. Hlm 1-9. 